\title{
Perbandingan Profil Lipid dan Penanda Inflamasi pada Pria Obesitas dan Non-Obesitas
}

\section{Comparison of Lipid Profiles and Inflammatory Markers in Obese and Non- Obesity Men}

\author{
Wimba Widagdho Dinutanayo ${ }^{1}$, Mayesti Akhriani ${ }^{2}$ \\ ${ }^{1}$ Jurusan Teknologi Laboratorium Medik, Politeknik Kesehatan Tanjungkarang, Indonesia \\ ${ }^{2}$ PT. Gizi Sehat Indonesia, Indonesia
}

\section{ARTICLE INFO}

\section{Article history}

Received date

28 Oct 2021

Revised date

12 Nov 2021

Accepted date

24 Nov 2021

Keywords:

Inflamation;

Lipid profile;

Obesity.

\section{Kata kunci:}

Inflamasi;

Profil lipid;

Obesitas.

\begin{abstract}
ABSTRAK
Obesity is a global health problem suffered by the people around the World, including Indonesian. There is adipose tissue dysfunction and fat distribution affecting the incidence of obesity-related diseases. The study aimed to compare the levels of lipid profiles (total cholesterol, HDL, LDL, and triglycerides) and inflammatory markers (ESR and leukocyte count) between groups with normal nutritional status and obesity. Data were collected using a cross sectional study with 14 young adult men for the normal nutritional status group with a BMI of $18,5-24,99 \mathrm{~kg} / \mathrm{m}^{2}$ and 14 young adult men for the obese group with a BMI $\geq 25 \mathrm{~kg} / \mathrm{m}^{2}$ in August-December 2019. The respondents aged 1835 years were measured body composition and tested for levels of lipid profiles and inflammatory markers. The results of statistical tests with independent-t test showed no difference in the number of leukocytes ( $p$-value $=0.08$ ) but there was a significant difference in ESR $(25,1 \pm 14,1$ vs $47,2 \pm 23,7, \mathrm{p}$-value $=0,006)$, total cholesterol $(126,6 \pm 26,4$ vs $175,5 \pm 32,0, \mathrm{p}$-value $=0,001)$, triglycerides $(113,3 \pm 38,3$ vs $161,5 \pm 46,9, \mathrm{p}=0,006)$ and $\operatorname{LDL}(53 \pm 18,4$ vs $95 \pm 27,3$, p-value $=0,001)$. The conclusion of this study is that there are significant differences in levels of total cholesterol, triglycerides, LDL and ESR between groups of individuals with normal nutritional status and obesity.
\end{abstract}

\begin{abstract}
Obesitas adalah sebuah masalah kesehatan global yang diderita oleh masyarakat, termasuk masyarakat Indonesia. Terdapat disfungsi jaringan adiposa serta distribusi lemak yang berpengaruh terhadap munculnya penyakit terkait obesitas.. Tujuan penelitian adalah mengetahui perbandingan kadar profil lipid (kolesterol total, HDL, LDL, dan trigiserida) dan penanda inflamasi (LED dan jumlah leukosit) antara kelompok berstatus gizi normal dan obesitas. Data diperoleh menggunakan cross sectional study dengan 14 responden untuk kelompok berstatus gizi normal dengan IMT 18,5-24,99 $\mathrm{kg} / \mathrm{m}^{2}$ dan 14 responden kelompok obesitas dengan IMT $\geq 25 \mathrm{~kg} / \mathrm{m}^{2}$ pada Agustus - Desember 2019. Responden pria berusia 18-35 tahun diukur komposisi tubuh dan dianalisis kadar profil lipid dan penanda inflamasi. Hasil uji statistik dengan independent-t test menunjukkan tidak adanya perbedaan jumlah leukosit $(p$-value $=0,08)$ tetapi ada perbedaan signifikan pada LED $(25,1 \pm 14,1$ vs $47,2 \pm 23,7, \mathrm{p}=0,006)$, kolesterol total $(126,6 \pm 26,4 \mathrm{vs} 175,5 \pm 32,0, p$ value $=0,001)$, trigliserida $(113,3 \pm 38,3$ vs $161,5 \pm 46,9, p$-value $=0,006)$ dan LDL $(53 \pm 18,4$ vs $95 \pm 27.3$, $p$-value $=0,001$ ). Kesimpulan penelitian ini adanya perbedaan signifikan kadar kolesterol total, trigliserida, LDL dan LED antara kelompok individu berstatus gizi normal dan obesitas.
\end{abstract}

\section{PENDAHULUAN}

Salah satu kondisi yang menjadi masalah pandemik global saat ini adalah obesitas. Prevalensi obesitas di dunia meningkat tiga kali lipat sejak tahun 1975. Pada tahun 2016, sebanyak 650 juta atau $13 \%$ penduduk dunia berusia lebih dari 18 tahun berada dalam keadaan obesitas (WHO, 2021). Di Indoneisa, prevalensi obesitas meningkat pada populasi penduduk 
dewasa yaitu sebesar $10,5 \%$ pada tahun 2007 , $14,8 \%$ pada tahun 2013 , kemudian meningkat lagi menjadi $21,8 \%$ pada tahun 2018 (Kementerian Kesehatan RI, 2018).

Obesitas menyebabkan terjadinya kondisi diabetes, dislipidemia, inflamasi, hipertensi hingga keadaan prokoagulan yang dapat berkembang menjadi penyakit kardiovaskular pada seorang individu (Bays et al., 2013; Grundy, 2004; Kyrou, 2018; Mandviwala, 2016; Zalesin, 2011). Obesitas terjadi ketika asupan nutrisi melebihi kalori yang dibutuhkan. Kelebihan nutrisi ini disimpan dalam bentuk trigliserida di sel adiposit yang menyebabkan terjadinya disfungsi pada jaringan adiposa. Gangguan fungsi jaringan adiposa pada obesitas (Day \& Bailey, 2011; Qatanani \& Lazar, 2007) terutama ditandai oleh hipertrofi adiposit, pengurangan kapasitas buffer lipid pada jaringan adiposa, peningkatan infiltrasi makrofag ke jaringan adiposa serta produksi sitokin pro-inflamasi, dan semuanya berkaitan dengan resistensi insulin (Goosens, 2008; Stinkens et al, 2015).

Abnormalitas kadar lipid pada individu dengan obesitas ditandai dengan meningkatnya VLDL, apolipoprotein B dan trigliserida. Kadar LDL pada umumnya meningkat namun sesungguhnya hal ini disebabkan karena peningkatan jenis LDL dengan densitas yang kecil yang mudah terperangkap pada dinding arteri.

Peningkatan asam lemak pada liver menjadi kunci terjadinya dislipidemia khususnya pada pasien obesitas, Terdapat tiga sumber utama yang meyebabkan hal ini terjadi. Pertama, peningkatan aliran asam lemak dari jaringan adiposa dengan massa yang membesar khususnya pada jaringan lemak visceral menuju liver. Selain itu, resistensi insulin pada pasien obesitas menurunkan aktifitas insulin sehingga menghambat proses lipolisis trigliserida. Sebagai konsekuensinya, terjadi peningkatan pemecahan trigliserida pada jaringan adiposa yang menyebabkan kadar asam lemak naik (Bays, et al., 2013; Yu \& Ginsberg, 2005).

Kedua, peningkatan sintesis asam lemak di liver pada pasien obesitas yang ditunjukkan oleh sejumlah studi. Hiperinsulinemia pada pasien obesitas yang telah mengalami resistensi insulin menjadi penyebab terjadinya hal ini. Insulin menstimulasi faktor transkripsi SREBP-1c yang meningkatkan ekspresi enzim yang dibutuhkan untuk sintesis asam lemak. Ketiga adalah pengambilan lipoprotein kaya dengan trigliserida oleh liver. Peningkatan chylomicron pada pasien obesitas ditunjukkan oleh sejumlah studi bersamaan dengan adanya sintesis asam lemak pada usus halus. Hal ini berakibat pada terjadinya peningkatan asam lemak menuju liver (Xiao, et al, 2016; Björnson, et al, 2017; Jacome-Sosa \& Parks, 2014; Dash, et al, 2015;).

Peningkatan asam lemak pada liver dari tiga proses tersebut berdampak pada meningkatnya sintesis trigliserida di liver dan proteksi terhadap Apo B-100 dari degradasi sehingga meningkatkan sekresi dari VLDL (Yu \& Ginsberg, 2005; Xiao et al, 2016).

Di sisi lain, terjadi kondisi pro-inflamasi pada obesitas yang diakibatkan oleh infiltrasi makrofag ke jaringan adiposa. Adipokin yang diproduksi oleh jaringan adiposit atau sel lemak dan sitokin yang diproduksi oleh makrofag juga mengubah proses metabolisme lemak ( $\mathrm{Yu}$ \& Ginsberg, 2005; Khovidhunkit, 2004; Karastergiou, 2012).

Adiponektin dan resistin merupakan adipokin yang berperan dalam metabolisme lipid. Sebuah studi menunjukkan adanya penurunan kadar adiponektin pada subjek dengan obesitas. Penurunan kadar adiponektin juga berkorelasi terhadap penurunan kadar HDL dan peningkatan kadar trigliserida (Blüher, 2020). Studi lain menunjukkan adanya peningkatan resistin pada subjek yang menderita obesitas dan berhubungan dengan penurunan HDL dan Apo A-1. Resistin berperan dalam stimulasi produksi VLDL di liver ketika sintesis Apo B, kolesterol, dan trigliserida meningkat ( $\mathrm{Yu} \&$ Ginsberg, 2005; Matheson et $a l, 2012)$.

Sitokin pro-inflamasi seperti IL-1 dan TNF memiliki peran dalam menstimulasi lipolisis pada adiposit sehingga berakibat kepada peningkatan asam lemak yang bersikulasi. Didalam liver, kedua sitokin ini juga berperan dalam sintesis trigliserida dan asam lemak. Munculnya sitokin pro-inflamasi juga berdampak kepada metabolisme HDL di mana salah satu penyebabnya adalah menurnya produksi dari Apo A-1 sebagai protein utama dari HDL (Khovidhunkit, 2004).

Penelitian ini bertujuan untuk melihat kadar profil lipid yang terdiri dari kolesterol total, LDL, HDL dan trigliserida serta penanda inflamasi yang diwakili oleh jumlah leukosit dan laju endap darah (LED) pada kelompok pria obesitas kemudian membandingkanya dengan kelompok pria non-obesitas.

\section{METODE}

Desain penelitian adalah deskriptif analitik dengan pendekatan cross-sectional. Partisipan yang terlibat dalam penelitian ini berjumlah 28 orang dengan rentang umur 18-35 tahun. 
Kelompok kontrol terdiri dari 14 pria berstatus gizi normal dengan IMT $18,5-24,9 \mathrm{~kg} / \mathrm{m}^{2}$, dan 14 orang kelompok kasus berstatus gizi obesitas dengan IMT $\geq 25,0 \mathrm{~kg} / \mathrm{m}^{2}$.

Jenis data adalah data primer yang didapat dari wawancara, pemeriksaan fisik dan pengambilan sampel darah yang diuji di laboratorium untuk mengetahui kadar profil lipid (cholesterol total, LDL, HDL, trigliserida) dan penanda inflamasi (laju endap darah dan jumlah leukosit).

Populasi penelitian ini adalah pria dewasa berusia 18-35 tahun. Pemilihan subjek penelitian menggunakan metode purposive sampling dengan kriteria inklusi tidak memiliki riwayat penyakit seperti diabetes, kardiovaskular, endokrin atau sindrom metabolik, inflamasi akut, atau kanker,tidak merokok dan tidak mengalami fluktuasi berat badan selama 6 bulan terakhir berdasarkan hasil wawancara.

Kelompok kontrol terdiri dari subjek penelitian yang sesuai dengan kriteria inklusi dan hasil pengukuran antropometri IMT pada rentang $18,5-24,99 \mathrm{~kg} / \mathrm{m}^{2}$, sedangkan kelompok kasus terdiri dari 14 subjek dengan kriteria inklusi dan status gizi obesitas dengan hasil pengukuran IMTnya $\geq 25,0 \mathrm{~kg} / \mathrm{m}^{2}$.

Setelah subjek penelitian terpilih dan menandatangani informed concent, subjek penelitian melakukan pengukuran berat badan dan komposisi tubuh yang terdiri dari persen massa otot, massa visceral fat, massa subcutaneous fat, dan massa otot skeletal menggunakan Karada Scan Omron metode BIA (Bioelectrical Impedance Analysis).

Pengumpulan data LED, jumlah leukosit, kolesterol total, trigliserida, LDL, HDL diawali dengan pengambilan darah pada kelompok kasus dan kontrol dan diujikan di Laboratorium Kimia Klinik dan Laboratorium Hematologi Poltekkes Tanjung Karang.

Seluruh data dianalisis untuk mengetahui rata-rata dan standar deviasi. Parameter profil lipid dan penanda inflamasi diuji normalitasnya. Analisis independent T-test digunakan untuk mengetahui perbedaan rata-rata kelompok kasus dan kontrol. Jika $p$-value menunjukkan <0,05 berarti adanya signifikan antar kelompok.

Penelitian ini telah mendapatkan ijin etik penelitian dari Komisi Etik Poltekkes Tanjungkarang dengan nomor 289/EA/KEPKTJK/X/2019.

\section{HASIL}

Tabel 1. Karakteristik subjek penelitian dengan parameter pemeriksaan status gizi, profil lipid dan penanda inflamasi.

\begin{tabular}{|c|c|c|}
\hline Parameter & Kontrol (14) & Obesitas (14) \\
\hline Usia (tahun) & $24,0 \pm 6,9$ & $24,8 \pm 4,9$ \\
\hline Indeks Massa & $22,0 \pm 2,1$ & $37,5 \pm 2,6$ \\
\hline $\begin{array}{l}\text { Tubuh (IMT) } \\
\left(\mathrm{kg} / \mathrm{m}^{2}\right)\end{array}$ & & \\
\hline Persen Lemak & $17,2 \pm 5,6$ & $34,0 \pm 2,6$ \\
\hline Lemak & $5,5 \pm 2,2$ & $22,5 \pm 3,3$ \\
\hline Visceral $(\%)$ & & \\
\hline $\begin{array}{l}\text { Lemak } \\
\text { Subkutan (\%) }\end{array}$ & $12,1 \pm 3,7$ & $24,9 \pm 1,2$ \\
\hline $\begin{array}{l}\text { Skeletal } \\
\text { Muscle (\%) }\end{array}$ & $35,1 \pm 24$ & $28,0 \pm 0,9$ \\
\hline $\begin{array}{l}\text { Laju Endap } \\
\text { Darah } \\
(\mathrm{mm} / \mathrm{jam})\end{array}$ & $25,1 \pm 14,1$ & $47,2 \pm 23,7$ \\
\hline $\begin{array}{l}\text { Jumlah } \\
\text { Leukosit }(\mu \mathrm{L})\end{array}$ & $8039,2 \pm 3288,5$ & $10075,0 \pm 2588,7$ \\
\hline $\begin{array}{l}\text { Kolesterol } \\
\text { Total (mg/dL) }\end{array}$ & $126,6 \pm 26,4$ & $175,5 \pm 32,0$ \\
\hline $\begin{array}{l}\text { High Density } \\
\text { Lipoprotein } \\
\text { (HDL) } \\
(\mathrm{mg} / \mathrm{dL})\end{array}$ & $50,9 \pm 12,2$ & $48,1 \pm 7,9$ \\
\hline $\begin{array}{l}\text { Low Density } \\
\text { Lipoprotein } \\
\text { (LDL) } \\
(\mathrm{mg} / \mathrm{dL})\end{array}$ & $53,0 \pm 18,4$ & $95,0 \pm 27,3$ \\
\hline $\begin{array}{l}\text { Trigliserida } \\
(\mathrm{mg} / \mathrm{dL})\end{array}$ & $113,3 \pm 38,3$ & $161,5 \pm 46,9$ \\
\hline
\end{tabular}

Total 28 partisipan mengikuti penelitian ini dengan dilakukan pengukuran komposisi tubuh serta pemeriksaan spesimen darah dalam keadaan berpuasa. Tabel 1 menunjukkan rata-rata umur adalah $24,8 \pm 4,9$ tahun pada kelompok obesitas dan $24 \pm 6,9$ tahun pada kelompok berstatus gizi normal.

Tabel 1 menunjukkan hasil perhitungan IMT dan komposisi tubuh antara dua kelompok. Rata-rata IMT kelompok obesitas yaitu $37,5 \pm 2,6 \mathrm{~kg} / \mathrm{m}^{2}$ termasuk obesitas kelas 2 (35$<40 \mathrm{~kg} / \mathrm{m}^{2}$ ) berdasarkan klasifikasi dari CDC. Kelompok obesitas memiliki rata-rata presentase lebih tinggi secara signifikan pada lemak visceral sebesar $17 \%$, lemak subkutan $12,8 \%$, dan lemak tubuh $16,8 \%$ dari kelompok kontrol ( $p$ value $=0,001 ; \quad p$-value $=0,001 ; \quad p$-value $=0,001$ secara berurutan). Sedangkan, persen otot pada kelompok obesitas lebih rendah sebesar 7,1\% dari kelompok kontrol $(p$-value $=0,001)$. 
Perbandingan Penanda Inflamasi dan Profil Lipid antara Kelompok Kontrol dan Kasus

Berdasarkan hasil pemeriksaan penanda inflamasi yaitu laju endap darah (LED) dan jumlah leukosit, rerata LED pada kelompok obesitas lebih tinggi secara signifikan dari kelompok kontrol $(47,2 \pm 23,7 \quad$ vs $25,1 \pm 14,1 \mathrm{~mm} / \mathrm{jam}, \quad p$-value $=0,006) \quad$ walaupun kedua kelompok menunjukkan rerata hasil yang abnormal (>15mm/jam). Sedangkan rerata jumlah leukosit pada kelompok obesitas tidak berbeda secara signifikan daripada kelompok kontrol dan masih berada dalam rentang normal (4000-10000sel/ $\mu \mathrm{L})$.

Hasil dari pemeriksaan profil lipid menunjukkan bahwa kelompok obesitas mengalami hipertrigliseridemia dibandingkan kelompok kontrol. Rata-rata kolesterol total, $(126,6 \pm 26,4 \quad$ vs $175,5 \pm 32,0, \quad p$-value $=0,001)$, trigliserida $(113.3 \pm 38.3$ vs $161.5 \pm 46.9, p$ value $=0,006)$ dan LDL $(53 \pm 18,4$ vs $95 \pm 27,3, p$ value $=0,001$ ) pada kelompok kontrol dan obesitas menunjukkan adanya perbedaan yang signifikan.

\section{Grafik 1. Perbedaan Signifikan antara Kelompok Kontrol dan Obesitas pada Parameter Kolesterol Total, LED, Trigliserida, dan LDL}
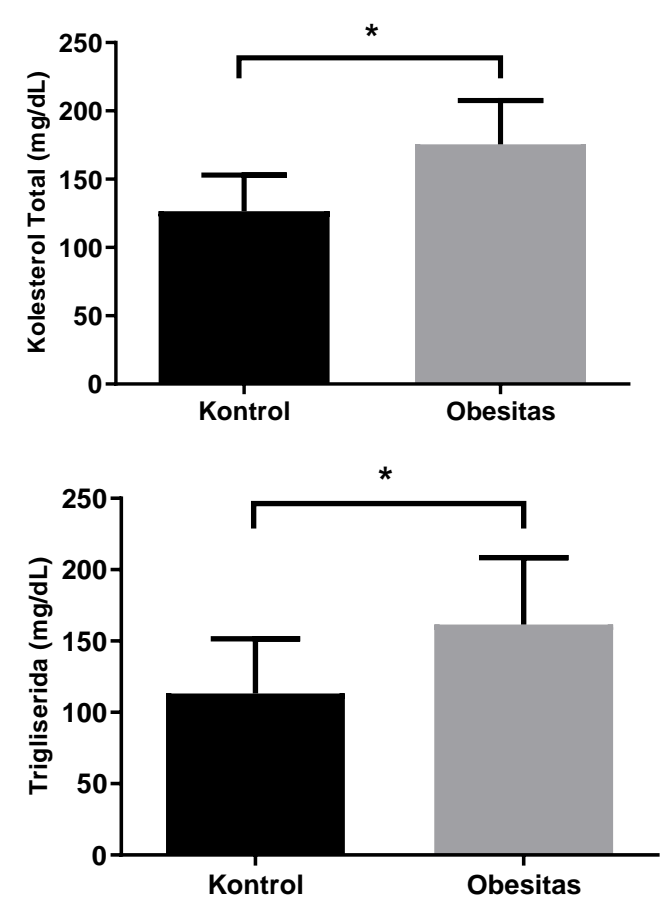
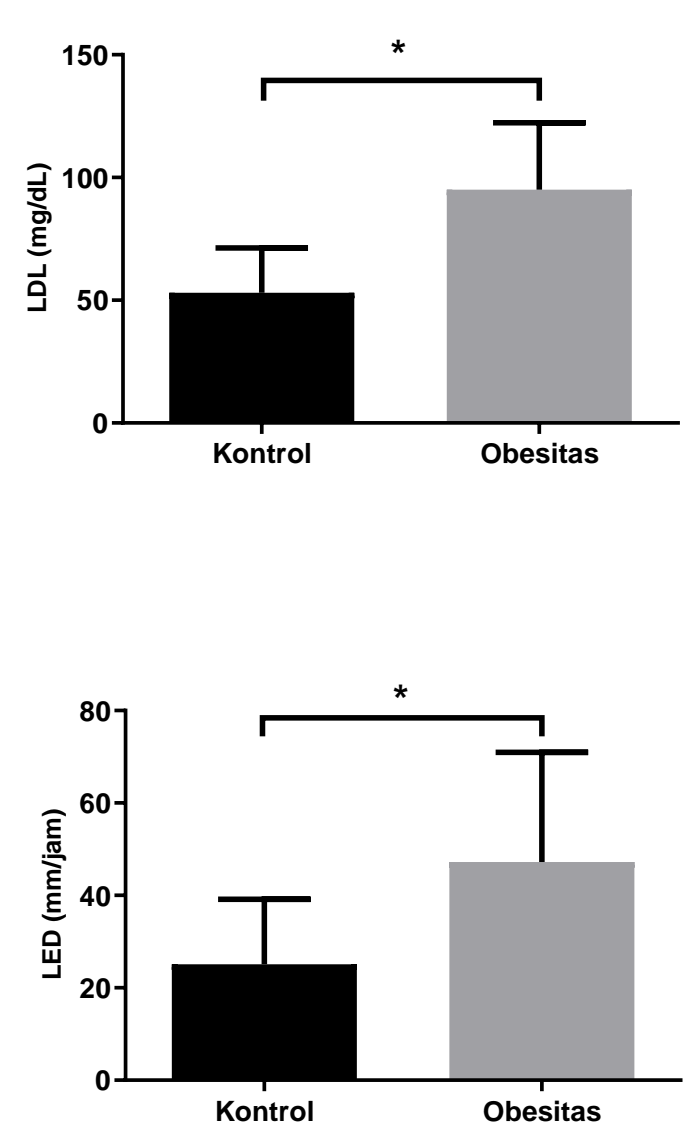

\section{PEMBAHASAN}

Studi ini memperlihatkan adanya perbedaan yang signifikan pada pemeriksaan komposisi tubuh walaupun kedua kelompok memiliki rerata umur dan jenis kelamin yang sama. IMT menjadi penentu status gizi seseorang termasuk pengkategorian obesitas. Pada studi ini, parameter komposisi tubuh lain memperlihatkan fitur yang khas pada subjek dengan obesitas di mana persen lemak tubuh, lemak visceral dan lemak subkutan meningkat melebihi batas normal $(10-<20 \%$; $0,5-9,5 \%$; <23\%).

Kadar lemak visceral yang tinggi berhubungan dengan tingginya kadar trigliserida dan VLDL serta rendahnya kadar HDL (Chan, et $a l$, 2004). Lemak visceral pada kelompok obesitas yang jauh lebih tinggi presentasenya menunjukkan penumpukan lemak lebih banyak pada bagian perut, ini disebut android obesity dan banyak terjadi pada pria (Karastergiou, 2012). Peningkatan asam lemak bebas di sekitar lemak visceral disertai kebiasaan asupan tinggi lemak yang menimbulkan peningkatan lipoprotein darah dan berkorelasi dengan sirkulasi asam lemak dari vena portal hati.

Studi ini menunjukkan adanya hipertrigliseridemia pada kelompok obesitas di 
mana rerata kadar lemak visceral dan subkutan kelompok ini berada pada tingkat yang tinggi. Hal ini sejalan dengan hasil penelitian dimana massa jaringan adiposa yang membesar khususnya pada lemak visceral akan meningkatkan aliran asam lemak menuju liver yang berdampak pada peningkatan sintesis trigliserida.

Selain itu, kelompok obesitas menunjukkan hasil yang lebih tinggi secara signifikan pada parameter kolesterol total dan LDL walaupun masih berada dalam rentang nilai normal. Hasil ini berkaitan dengan kelompok obesitas yang tidak terdiagnosa penyakit degeneratif pada studi ini.

Individu dengan obesitas yang tidak mengalami abnormalitas profil lipid dan tidak terdiagnosa penyakit degeneratif termasuk kriteria Metabolic Healthy Obese (MHO). Hal ini sejalan dengan hasil penelitian ini dimana kadar kolesterol total dan LDL pada kelompok obesitas masih dalam rentang normal dan hanya terjadi kenaikan trigliserida yang melebihi batas normal. Tidak adanya gangguan metabolisme dapat mengurangi risiko diabetes tipe 2 dan penyakit kardiovaskular pada $\mathrm{MHO}$, tetapi risikonya masih lebih tinggi daripada orang yang sehat dan berstatus gizi normal (Blüher, 2020).

Faktor-faktor seseorang mengalami MHO adalah usia, level aktifitas fisik dan proporsi lemak visceral. Pada studi ini, subjek obesitas memiliki rata-rata usia yaitu 24,8 tahun yang termasuk kategori dewasa muda. MHO merupakan fenotipe sementara yang sering ditemui pada individu obesitas berusia lebih muda yang disertai kebiasaan hidup lebih baik seperti tidak mengonsumsi alkohol, tidak merokok dan aktifitas fisik yang rutin. Seiring bertambahnya usia, prevalensi MHO menjadi lebih kecil karena kemungkinan besar akan berubah menjadi obesitas dengan sindrom metabolik jika tidak mendapatkan terapi yang sesuai terkait

\section{DAFTAR PUSTAKA}

Bays, H. E., Toth, P. P., Kris-Etherton, P. M., Abate, N., Aronne, L. J., Brown, W. V., Gonzalez-Campoy, J. M., Jones, S. R., Kumar, R., La Forge, R., \& Samuel, V. T. (2013). Obesity, adiposity, and dyslipidemia: A consensus statement from the National Lipid Association. Journal of Clinical Lipidology, 7(4), 304-383. https://doi.org/10.1016/j.jacl.2013.04.001.

Björnson, E., Adiels, M., Taskinen, M. R., \& Borén, J. (2017). Kinetics of plasma penurunan berat badan (Matheson, et al, 2012). LED pada kedua kelompok studi ini melebihi batas normal dan terjadi perbedaan yang signifikan dimana nilai LED pada kelompok obesitas lebih tinggi daripada kelompok normal. Sedangkan jumlah leukosit pada kelompok obesitas lebih tinggi daripada kelompok kontrol walaupun tidak signifikan dan masih berada dalam rentang nilai normal. LED dan jumlah leukosit merupakan parameter inflamasi yang bersifat non spesifik sehingga rerata nilai LED yang melebihi batas normal pada kelompok kontrol dapat terjadi karena faktor penyebab inflamasi atau infeksi yang lain. Karakteristik obesitas salah satunya adalah inflamasi yang ditimbulkan oleh adanya sekresi sitokin proinflamasi. Sitokin-sitokin seperti IL-6, IL-8, TNF alfa ini diproduksi oleh makrofag pada jaringan adiposa yang berefek terhadap produksi CRP, fibrinogen, dan haptoglobin oleh liver. Hal ini menyebabkan naiknya kadar LED dan jumlah leukosit sebagai penanda inflamasi (Boutens \& Stienstra, 2016; Kang, 2016).Sebuah studi dari Ryder pada tahun 2014 memperlihatkan adanya korelasi positif anatar jumlah leukoisit dan IMT. Studi tersebut juga menunjukkan tidak adanya peningkatan jumlah leukosit yang signifikan pada kelompok MHO sejalan dengan hasil studi ini, namun jumlah leukosit meningkat signifikan pada kelompok obesitas dengan resistensi insulin (Ryder, 2014).

\section{SIMPULAN}

Simpulan dari studi ini adalah terdapat perbedaan secara signifikan pada parameter total persen lemak tubuh, lemak visceral, lemak subkutan, otot skeletal, trigliserida, kolesterol total, LDL dan LED antara kelompok obesitas dan non-obesitas di Kota Bandar Lampung.

triglycerides in abdominal obesity. Current opinion in lipidology, 28(1), 11-18. https://doi.org/10.1097/MOL.0000000000 000375.

Blüher M. (2020). Metabolically Healthy Obesity. Endocrine reviews, 41(3), 405-420. https://doi.org/10.1210/endrev/bnaa004.

Boutens, L., \& Stienstra, R. (2016). Adipose tissue macrophages: going off track during obesity. Diabetologia, 59(5), $\quad$ 879-894. https://doi.org/10.1007/s00125-016-3904-9 
Chan, D. C., Barrett, H. P., \& Watts, G. F. (2004). Dyslipidemia in visceral obesity: mechanisms, implications, and therapy. American journal of cardiovascular drugs: drugs, devices, and other interventions, 4(4), 227-246. https://doi.org/10.2165/00129784200404040-00004.

Dash, S., Xiao, C., Morgantini, C., \& Lewis, G. F. (2015). New Insights into the Regulation of Chylomicron Production. Annual review of nutrition, 35, 265-294. https://doi.org/10.1146/annurevnutr-071714-034338

Day, C., \& Bailey, C. J. (2011). Obesity in the pathogenesis of type 2 diabetes. The British Journal of Diabetes \& Vascular Disease, 11(2), 55-61. https://doi.org/10.1177/1474651411407418

Goossens G. H. (2008). The role of adipose tissue dysfunction in the pathogenesis of obesity-related insulin resistance. Physiology \& behavior, 94(2), 206-218. https://doi.org/10.1016/j.physbeh.2007.10.010

Grundy, S. M. (2004). Obesity, Metabolic Syndrome, and Cardiovascular Disease. The Journal of Clinical Endocrinology \& Metabolism, 89(6), 2595-2600. https://doi.org/10.1210/jc.2004-0372.

Jacome-Sosa, M. M., \& Parks, E. J. (2014). Fatty acid sources and their fluxes as they contribute to plasma triglyceride concentrations and fatty liver in humans. Current opinion in lipidology, 25(3), 213-220. https://doi.org/10.1097/MOL.0000000000 000080.

Kang, Y. E., Kim, J. M., Joung, K. H., Lee, J. H., You, B. R., Choi, M. J., Ryu, M. J., Ko, Y. B., Lee, M. A., Lee, J., Ku, B. J., Shong, M., Lee, K. H., \& Kim, H. J. (2016). The Roles of Adipokines, Proinflammatory Cytokines, and Adipose Tissue Macrophages in Obesity-Associated Insulin Resistance in Modest Obesity and Early Metabolic Dysfunction. PloS one, 11(4), e0154003. https://doi.org/10.1371/journal.pone.0154003.

Karastergiou, K., Smith, S. R., Greenberg, A. S., \& Fried, S. K. (2012). Sex differences in human adipose tissues - the biology of pear shape. Biology of sex differences, 3(1), 13. https://doi.org/10.1186/2042-6410-3-13.

Kementerian Kesehatan RI. (2018). Laporan Nasional Riset Kesehatan Dasar 2018. Badan Penelitian dan Pengembangan Kesehatan Kemenkes RI.
Khovidhunkit, W., Kim, M. S., Memon, R. A., Shigenaga, J. K., Moser, A. H., Feingold, K. R., \& Grunfeld, C. (2004). Effects of infection and inflammation on lipid and lipoprotein metabolism: mechanisms and consequences to the host. Journal of lipid research, 45(7), 1169-1196. https://doi.org/10.1194/j1r.R300019-JLR200.

Kyrou, I., Randeva, H. S., Tsigos, C., Kaltsas, G., \& Weickert, M. O. (2018). Clinical Problems Caused by Obesity. In K. R. Feingold (Eds.) et. al., Endotext. MDText.com, Inc.

Matheson, E. M., King, D. E., \& Everett, C. J. (2012). Healthy lifestyle habits and mortality in overweight and obese individuals. Journal of the American Board of Family Medicine: $J A B F M, 25(1)$,

9-15. https://doi.org/10.3122/jabfm.2012.01.110164 Mandviwala, T., Khalid, U., \& Deswal, A. (2016). Obesity and Cardiovascular Disease: a Risk Factor or a Risk Marker?. Current atherosclerosis reports, 18(5), 21. https://doi.org/10.1007/s11883-016-0575-4

Qatanani, M., \& Lazar, M. A. (2007). Mechanisms of obesity-associated insulin resistance: many choices on the menu. Genes \& development,21(12), 1443-1455.

https://doi.org/10.1101/gad.1550907.

Ryder, E., Diez-Ewald, M., Mosquera, J., Fernández, E., Pedreañez, A., Vargas, R., ... Fernández, N. (2014). Association of obesity with leukocyte count in obese individuals without metabolic syndrome. Diabetes \& Metabolic Syndrome: Clinical Research \& Reviews, 8(4), 197-204. doi:10.1016/j.dsx.2014.09.002.

Stinkens, R., Goossens, G. H., Jocken, J. W., \& Blaak, E. E. (2015). Targeting fatty acid metabolism to improve glucose metabolism. Obesity reviews: an official journal of the International Association for the Study of Obesity, 16(9), 715-757. https://doi.org/10.1111/obr.12298

WHO. (2021). Obesity and overweight. https://www.who.int/news-room/factsheets/detail/obesity-and-overweight.

Xiao, C., Dash, S., Morgantini, C., Hegele, R. A., \& Lewis, G. F. (2016). Pharmacological Targeting of the Atherogenic Dyslipidemia Complex: The Next Frontier in CVD Prevention Beyond Lowering LDL Cholesterol. Diabetes, 65(7), 1767-1778. https://doi.org/10.2337/db16-0046 
Yu, Y. H., \& Ginsberg, H. N. (2005). Adipocyte Signaling and Lipid Homeostasis. Circulation Research, 96(10), 10421052.https://doi.org/10.1161/01.res.000016 5803.47776.38.
Zalesin, K. C., Franklin, B. A., Miller, W. M., Peterson, E. D., \& McCullough, P. A. (2011). Impact of obesity on cardiovascular disease. The Medical clinics of North America,95(5), 919-937. https://doi.org/10.1016/j.mena.2011.06.005. 